http://lexikos.journals.ac.za

\title{
Foreign Words as a Problem in Standardisation / Lexicography: English and Afrikaans Loan-words in isiXhosa*
}

\author{
Anja Drame, Department of African Studies, University of Leipzig, Leipzig, \\ Germany (anjadrame@hotmail.com)
}

\begin{abstract}
Languages are not static systems. They develop and change, add new items while others become outdated. These changes can be clearly observed in the lexicon especially. No language can afford to ignore or neglect foreign influence. Due to globalisation, especially English gains more and more influence on other (also European) languages. In developing countries, the languages of the former colonisers also still have an enormous impact on the indigenous languages. Some of these nations are slowly heading towards endogenous language policies which demands the modernisation of the technical vocabulary. This is however a costly and time-consuming process. In this regard language planners often prefer borrowing from foreign sources as a quick and therefore cheap method.

The first part of this paper deals with the discussion amongst linguists, sociolinguists and lexicographers about the extent to which foreign words should be allowed in an indigenous language. The second part looks at the example of isiXhosa, one of South Africa's eleven official languages, which is strongly influenced by foreign words, especially English and Afrikaans, and shows problems and methods of the integration of foreign words into the isiXhosa grammatical structure.
\end{abstract}

Keywords: FOREIGN WORDS, ISIXHOSA, ENGLISH, AFRIKAANS, BAHASA INDONESIA, RUSSIAN, ESTONIAN, GERMAN, LANGUAGE POLICY, LANGUAGE PURISM, LSP, MORPHOLOGY, SEMANTICS, PHONOLOGY

Zusammenfassung: Fremdwörter als Problem in der Standardisierung/ Lexikographie: Englische und afrikaanse Lehnwörter in isiXhosa. Sprachen sind keine statischen Systeme. Sie entwickeln und verändern sich, fügen neue Bestandteile hinzu, während andere veralten. Diese Vorgänge lassen sich besonders deutlich im Lexikon einer Sprache beobachten. Keine Sprache kann es sich leisten fremde Einflüsse zu ignorieren oder zurückzuweisen. Aufgrund von Globalisation gewinnt vor allem das Englisch immer mehr Einfluss auf andere (auch europäische) Sprachen. Aber auch in Entwicklungsländern beeinflüssen die Sprachen der früheren Kolonisatoren die einheimischen Sprachen überaus viel. Einige dieser Nationen bewegen sich nach und nach in Richtung einer endogenen Sprachpolitik, was die Modernisierung des

* This paper was presented at the Fifth International Conference of the African Association for Lexicography, held at the University of Stellenbosch, Stellenbosch, 3-5 July 2000.

Lexikos 10 (AFRILEX-reeks/series 10: 2000): 231-241 
technischen Vokabulars dringend nötig macht. Dies is jedoch ein kosten- und zeitaufwendiges Unterfangen. Daher bevorzugen Sprachplaner oftmals die relativ schnelle und somit billige Methode der Entlehnung aus fremden Sprachen.

Der erste Teil dieses Aufsatzes behandelt die Diskussion unter Linguisten, Soziolinguisten und Lexikographen, zu welchem Anteil Fremdwörter in einer einheimischen Sprache aufgenommen werden sollten. Der zweite Teil betrachtet das Beispiel des isiXhosa, eine von Südafrikas elf offiziellen Sprachen und stark von Fremdwörtern, besonders Englisch und Afrikaans, beeinflusst und zeigt Probleme und Methoden der Integration von Fremdwörtern in die grammatische Struktur des isiXhosa.

Stichwörter: FREMDWÖRTER, ISIXHOSA, ENGLISCH, AFRIKAANS, BAHASA INDONESIA, RUSSISCH, ESTONISCH, DEUTSCH, SPRACHPOLITIK, SPRACHPURISMUS, FACHSPRACHEN, MORPHOLOGIE, SEMANTIK, PHONOLOGIE

\section{Foreign words as a problem in language planning}

In this paper, I define a foreign word as a word whose phonic shape does not conform to the native phonemic pattern of the language. In its common sense it is "a word, taken from another language more or less unchanged", or, "a word of which you can tell by pronunciation, stress or orthography that it is not of native origin" (Wahrig 1968, translated and slightly changed by the author). Foreign words play an important role in language planning processes in developing nations.

Language planning is a deliberate, planned language change. It is a problem-solving, future-oriented activity by organisations, established for this purpose (Rubin and Jernudd 1971). It is an activity closely connected with lexicography. Dictionaries not only describe a language. Many modern dictionaries are prescriptive works. They function as reference works and therefore play an important role in the implementation of new terminology. Loan-words, i.e. foreign words which are phonologically and morphologically adapted and integrated into another language, and foreign words exist in almost every European language and have at different times caused different reactions pro and contra.

Language purism predominated German lexicography for a long time. The first German Fremdwörterbuch was published as early as 1571. In 1801 Campe's Wörterbuch zur Erklärung und Verdeutschung der unserer Sprache aufgedrungenen fremden Ausdrücke was published. Campe did not only explain foreign words in his dictionaries but also substituted them with German equivalents. Distinction was made between the origin of the words. English and Dutch words were considered as foreign but the main focus was on words from French and other non-Germanic languages (Kirkness 1976). In the new Duden Anglicisms and words from other languages form a great part of the entries.

Nationalistic purism is, however, losing ground in many countries. With 
Israel as example, Fellman and Fishman (1977) warn that if a language is too purist, especially in science, it hampers the natural language change and development in language structure which implies that phoneme and morpheme inventories are to a certain degree closed systems and that the lexicon is open but very limited. It also hampers standardisation because in many instances of higher education students are already familiar with English terms.

The fact that a word is understood by several nations enhances international communication. Internationalisms make it easier to learn the other's language. But internationality cannot be the only principle to be considered when evaluating foreign words, because a word may be understood by intellectuals but not the great mass of the people (Tauli 1968).

The most common arguments against foreign words are on the one hand the already mentioned purism. On the other hand they are criticised for their lack of transparency. Laypeople do not understand them, because they are unmotivated and etymologically not clear. A word is transparent if the concept it represents is understood without further explanation, for instance: Blinddarmentzündung v. Appendicitis.

But a compound or a derived word is only clear if it literally refers to the designated concept. The fact that people do not understand foreign words often depends on the circumstance that people do not understand the concept. Empirical tests prove this to be true. When one encounters a new word whose meaning one does not know, it matters little whether the word is a foreign or a native word. For example, the German Hubschrauber is not clearer than Helicopter if one does not know the thing it describes. Nevertheless, motivated words are easier to memorise than unmotivated words.

A very common statement is that foreign words obstruct communication between intellectuals and ordinary people. One can argue against this that it is more a question of style and audience. If precise learned terms, be they foreign or native words, can be avoided in a popular presentation, they should be. However, if precise terms are needed, for instance in a scientific text, and they are lacking in a particular language, foreign words are unavoidable. This speaks against having different terms for the different levels of special subject discourse such as jargon or scientific language, as is the case in all European languages. In German, for instance, especially in scientific language, foreign words play an important role. Therefore dictionaries for special purposes as well as terminological databases should include both jargon and scientific expressions and provide clear, detailed definitions as well as information about the context of use of these lexical items connected with examples of their typical use in a text.

Abdulaziz (1989) argues that borrowing of international terms should be mixed with coining of local terms so as to preserve the identity of the African languages. Although many terms have been coined by means of borrowing, there are also a great number of very resourceful modern native terms which sometimes go hand in hand with the European expressions. 
From the point of economy, foreign words have some disadvantages. Foreign phonemics and stress patterns cause problems and are inconvenient for the speakers. This, of course, differs strongly among different language groups. Foreign phonemic elements should not be integrated into international words in native languages. Either the phonic structure should be adapted to the native language or an adequate native word should be used.

Foreign words are also often very long and cumbersome and thus more difficult to pronounce. But this is not only a problem with foreign words, sometimes a native word also is a long compound or circumscription (Tauli 1968). Swahili compounding is, according to Batibo (1992), a very transparent method of term creation which can be applied to isiXhosa as well: umabonakude (bona see, kude afar) as opposed to iTV/itelevizhini.

Long words and circumscriptions are contrary to the tendency towards modern, short words and are therefore uneconomical. The speakers of the discourse community may prefer an abbreviation if it is often used. But this again is contradictory to transparency: abbreviations of long words or circumscriptions lose transparency and are therefore probably harder to memorise. In this case adapted foreign words are to be preferred.

From the aesthetic point of view, there are two arguments to be considered:

1. The use of foreign words is to a certain degree a question of style, particularly in science. In scientific literature the foreign word can be preferred. If one language has two variants of an expression (a native word and a foreign word), it serves the purpose of variety.

2. Acceptance must be considered as most important. If a large part of the population does not accept a foreign word for emotional reasons, it must not be insisted that it should be used. A country which was under the rule of a colonial power for long, might feel a certain reluctance to the colonial language. Although necessary because of a lack of native terminology, it might not appreciate terms from the colonial language and replace them with either native words or words from another more acceptable language. Tauli (1968) gives as an example that Estonian in 1920 substituted the word tänav, originally an old Germanic loan-word, for the Russian loan-word uulits, street. Linguists rejected tänav as imprecise (it originally referred only to a village street) but the ordinary people were unaware of its origin and therefore accepted it.

In the area of the former Soviet Union, all the national languages borrowed about $70-80 \%$ of their lexicon from Russian as imposed by the Soviet government. This uniformity facilitated the preparation of educational materials and thus promoted education in those languages as well as literacy in Russian as a second language. At the same time Russian was strengthened. 
To give another example: Bahasa Indonesia was promoted since Indonesia's independence in 1949. The strategies were not like those in the case of Russian in Estonia, but borrowings for the growing demands in the fields of industry, government, education, commerce, science and technology came from different sources. They were either taken from existing words or morphemes in Bahasa, or other Indonesian languages, or loan-translations from or an influx of foreign terms (English and Dutch). The controversy mainly concerned the source of the borrowings: European languages, mainly English for the fields of modern science and technology, and the languages from which borrowings traditionally come (mainly Sanskrit, the language of Indonesia's height of political power in South East Asia from the 7th to the 14th century, used especially in the fields of literature, culture, and scholarship). Although Sanskrit loan-words are used by military leaders and politicians to arouse nationalistic sentiments in support of their politics and English by other sections of the society to express modernity, it is a good example of a compromise between two poles of corpus planning: modernity and authenticity, which, according to Fishman (1983), must both be present for successful modernisation (Cooper 1989).

Language planning does not take place in a vacuum. A wide range of social factors must be considered and in the end the speakers of a certain language or discourse group alone decide if they prefer and want to use a foreign or a native word.

Not much research has been done on the acceptance of foreign words or on language inherent coinages in isiXhosa, but one can assume that they are relatively well accepted. The South African Broadcasting Corporation (SABC) extensively uses foreign loan-words for the news in the African languages. These are understood by the young urban population and cause only a few complaints by language purists. Vice versa, if the SABC were to use more language inherent versions, people would have problems to understand these. Dictionaries should therefore include those foreign expressions in the way they are used by the speakers and give information about the source language. The Greater Dictionary of Xhosa which is compiled at the University of Fort Hare, works according to a language descriptive rather than a prescriptive way. This implies that Anglicisms and words of Afrikaans origin are included and their origin is indicated as can be seen from the examples $i$-sekile $<$ Afr. sekel and $i$-se$k i s i<$ Eng. circus. (Tones are not considered in this paper.)

\section{Afrikaans and English words in isiXhosa}

IsiXhosa is a Nguni language spoken in the Eastern Cape, especially in the areas of the former Transkei and Ciskei. IsiXhosa is not a homogeneous language, but has a multitude of dialects (e.g. Ngqika, Gcaleka, Thembu, Mfengu, Mpondo, Xesibe, and Bomvana) which are largely intercomprehensible despite variation that might occur in their lexicon. Apart from this, the written stan- 
dard differs considerably from the spoken varieties. The Ngqika and Gcaleka dialects are the closest to the standard. The development of an orthography by John Bennie in 1824 was based on these two dialects.

The typical feature of isiXhosa nouns is that they also, like those in other Bantu languages, consist of a stem and a class marker. The stem contains the basic semantics of the word while the class markers represent the categorical class.

$\begin{array}{lll}\text { Example: } & \text { umfazi }(/ \mathrm{u}-/-/-\mathrm{m}-/-/ \text {-fazi } /) & \text { woman } \\ & \text { abafazi (/a-/ - /-ba-/ - /-fazi/) } & \text { women } \\ & \text { ubufazi } & \text { womanhood } \\ \text { isifazi } & \text { typical of women as a group }\end{array}$

The language is influenced by other Bantu languages (especially seSotho), English and Afrikaans. It was formerly largely influenced by Khoisan languages the origin of the clicks - but today there is no living contact anymore. Only little is known about the influence of the Khoisan languages on the isiXhosa lexicon (Jafta 1987), but it is assumed that approximately 15\% of the isiXhosa vocabulary is of Khoisan origin.

Only $22 \%$ of the language standardisation strategies in isiXhosa are language inherent strategies, the remaining $78 \%$ are loan-words or foreign words. Of the European languages, English is about $57 \%$ more important than Afrikaans (Britz 1983). Reasons for this are that education of isiXhosa speakers is mainly through English as medium of instruction and therefore English loanwords are integrated with a higher frequency. English is also seen as a prestige language, the language of the ANC. Afrikaans had and still has some pragmatic value. Other Bantu languages have their influence mainly in the big cities where people from different language groups live together and in the NorthEastern Cape where the isiXhosa area borders on Lesotho.

The usage of loan-words depends mainly on different social factors like age, geographical area, and education. For example, the loan-words ukuprakthiza or ilayibrary are never or seldom used in rural areas where isiXhosa exists in its most natural form and bilingualism is limited to teachers or maybe nurses at hospitals.

\subsection{Morphology}

The isiXhosa noun structure consists of two or three morphemes (pre-classmarkers), basic class-marker and the stem.

English or Afrikaans nouns which consist only of one morpheme do not cause problems since they can easily be transformed into isiXhosa by adding the class markers. If the English or Afrikaans word consists of more than one morpheme it will still be treated the same way, i.e. the whole polymorphemic foreign word forms the stem and the class-markers are added to it. 


$\begin{array}{lll}\text { Examples: } & \text { sweets } & >\text { iswitisi or iiswitisi } \\ \text { paper } & >\text { i-phepha } \\ \text { lekkers } & >\text { ilekese or iilekese } \\ \text { sussie } & >\text { usisi } \\ \text { heiden } & >\text { u-m-hedeni }\end{array}$

We can conclude that the foreign structure of the English or Afrikaans loanwords does not cause a problem for integration into isiXhosa.

The structure of an isiXhosa verb consists of three morphemes: core (basis, semantics), subject-marker and final marker (mood and other categorical functions).

$\begin{array}{lll}\text { Examples: } & \text { hamb-a! go! } \\ & \text { ba-fund-e of that you learn }\end{array}$

Here again, as with nouns, there are no difficulties with verbs of only one morpheme. Afrikaans and English verbs consisting of more than one morpheme are treated like monomorpheme words.

$\begin{array}{rll}\text { Examples: } & \text { saag } & >\text {-sarh- } \\ \text { pass } & >- \text { pas- }\end{array}$

We can conclude that the transmorphology from English or Afrikaans into isiXhosa is more or less regular. Foreign words can be completely integrated into the morphological structure of isiXhosa.

\subsection{Semantics/Transsemantics}

Transsemantics is the process in which a loan-word is integrated into isiXhosa semantics. We can assume that there are at least four transsemantic processes possible:

(a) complete integration (the concept is taken over unaltered from English or Afrikaans),

Examples: koffie [+ warm drink + made from coffee beans] > ikofu [+ warm drink + made from coffee beans]

receipt [+ written + acknowledgement that something is received] $>$ irisithi [+ written + acknowledgement that something is received]

(b) narrowed meaning (the concept includes more constituents in English or Afrikaans),

Examples: skool [+ educational institution + teachers and pupils + group of 
artists/scientists following the same principle + large crowd + meeting] > isikolo [+ educational institution + teachers and pupils]

beer [+ European kind of beer + African kind of self-brewed beer] $>$ ibhiya [+ European beer] (in contrast to umqombothi [+ African beer])

order [+ request (to supply something) + (proper/usual) sequence + command] $>$ iodolo [+ request (to supply something) + sequence]

(c) broadened meaning or semantic extension (the original meaning of the loan-word from English or Afrikaans has one or more additional meanings), or

Examples: balloon [+ form of a ball + filled with air $]>$ ibhaloni $[+$ form of a ball + filled with air + flight instrument]

gas [+ element + airlike substance + heat source $]>$ igesi $[+$ element + airlike substance + heat source + electricity $]$

(d) semantic shift (the meaning of the loan-word from English or Afrikaans changes in the process of integration into isiXhosa, sometimes considerably, resulting in false friends).

Examples: kandelaar [+ candlestick] > ikhandlela [+ candle] railway [+ tracks + public institution] $>$ uloliwe [+ train]

The number of the completely integrated words is by far bigger than the number resulting from the other processes, which means that complete integration is the most common process.

\subsection{Phonological assimilation}

Lexical borrowing is closely connected to phonological assimilation. To a large extent, foreign sounds undergo regular changes.

$\begin{array}{lll}\text { Examples: } & / \mathrm{r} / & >/ 1 / \\ & \text { rok } & >\text { ilokhwe } \\ & \text { dinner } & >\text { idinala } \\ \text { supper } & >\text { isaphala } \\ \text { lorry } & >\text { iloli }\end{array}$

Especially in modern adoptive words, Zulu or isiXhosa use /r/ more and more as in the example of dairy > ideri.

The phoneme $/ \mathrm{r} /$ is becoming a regular phoneme although restricted to 
lexical items from English and Afrikaans. Sometimes, even /rr/ is used, especially by modern urban-educated speakers. A certain regularity can be observed, but there are also examples of irregular assimilation of foreign phonemes:

$$
\begin{array}{cll}
\text { Examples: } & & \\
{[\theta]>[\text { th }]} & \text { theology } & >\text { ithiyoloji } \\
{[\theta]>[\mathrm{f}]} & \text { thimble } & >\text { imfimbolo } \\
& \text { bath } & >\text { ibafu }
\end{array}
$$

The syllable structure in a Bantu language word is the skeletal or canonical structure of CVCV, which means almost every word ends in a vowel, whereas English and Afrikaans words usually do not employ vowels as final phonemes. For integration into the isiXhosa phonological structure, this means that a vowel is added. A tendency can be observed to solve this problem but again there is no absolute regularity. Loan-words which end on a labial phoneme usually take a back vowel, in most cases /u/.

$$
\begin{array}{lll}
\text { Examples: } & \text { lab } & >\text { ilebhu } \\
& \text { pump } & >\text { impompo } \\
& \text { lap } & >\text { ilaphu } \\
& \text { waskom } & \text { > ivasikomu }
\end{array}
$$

If the consonant is nonlabial, it will be a front vowel like /i/.

Sound clusters are uncommon in the isiXhosa grammatical structure. If there is a consonant combination in Afrikaans or English which is not allowed in or clashes with the isiXhosa phonetic system, a vowel is usually placed in between. This vowel insertion is also known as vowel epenthesis. It includes the insertion of a vowel between two consonants as well as after a consonant in a syllable final position (Batibo 1996).

$$
\begin{array}{lll}
\text { Examples: } & \begin{array}{l}
\text { broek } \\
\text { cricket }
\end{array} & >\text { ibhulukhwilikithi }
\end{array}
$$

Sometimes this foreign combination is kept, although it clashes the isiXhosa system.

$$
\begin{array}{lll}
\text { Examples: } & \text { flag } & >\text { ifleki } \\
& \text { dribble } & >\text {-dribula } \\
& \text { drink } & >\text { idrinki }
\end{array}
$$

\subsection{Morphological assimilation}

With verbs, loan-words in their basic form take the final vowel /a/ to form the 
verbal stem.

$\begin{array}{lll}\text { Examples: } & \text { bore } & >\text {-bhola } \\ \text { dance/dans } & >\text { danisa } \\ \text { phone } & >\text { fowuna }\end{array}$

To this stem the normal pre- and suffixes are added according to mood, tense, aspect and other additional semantic aspects.

Examples: om te jaag >-dyarha (to chase)

$$
\begin{aligned}
\text { jaag } & >\text { dyarha } \\
& >\text { udyarha (he chases) } \\
& >\text { udyarhile (he has chased) }
\end{aligned}
$$

Noun loan-words undergo morphological assimilation as well. According to other Bantu language noun specific patterns, a class marker will be added.

$\begin{array}{cll}\text { Examples: } & & \\ \text { Class 1(a) } & \text { sussie } & >\text { u-sisi } \\ \text { boetie } & >\text { u-bhuti } \\ \text { Class 5 } & \text { esel } & >\text { i-esile } \\ & \begin{array}{l}\text { band } \\ \text { pincers }\end{array} & >\text { i-bhanti } \\ \text { Class } 9 & \text { i-mpintshisi } \\ & \text { coffee } & >\text { i-kofu }\end{array}$

In most cases loan-words are integrated in one of these three classes. Exceptions are loan-words with an initial consonant combination beginning with /s/, such as Afrikaans stoel. They are usually integrated in class 7. A vowel, mostly /i/, is inserted between /s/ and the other consonant.

$\begin{array}{lll}\text { Examples: } & \text { stoel } & >\text { i-situlo } \\ & \text { spieël } & >\text { isipili } \\ & \text { straat } & >\text { isitalato }\end{array}$

Like verbs, nouns too can be derived by pre- and suffixation.

$$
\begin{aligned}
\text { Examples: dorp } & >\text { i-dolophu (village) } \\
& >\text { iidolophu (villages) } \\
& >\text { idolophana (small village) }
\end{aligned}
$$

\section{Conclusion}

The discussion on foreign words has not been terminated yet. Their influence will increase with the growth of globalisation. In South Africa, with its tenden- 
cies towards English monolingualism, there will be an even greater increase of Anglicisms in the African languages and probably in Afrikaans as well. Will it be useful to develop and standardise native terminology and words people are not likely to use? Or will language awareness increase if more projects such as tertiary education in the native languages are initiated? And which role will lexicography play in the implementation of modernised terminology?

The aim of languages, especially languages for special purposes, is to function as a vehicle for communication between people and enable the exchange of ideas and information among speakers of a discourse group. If this goal is reached by the use of foreign words, why should a purist language policy be forced? The German of today would not have existed if it had not been for foreign influences, as can be illustrated by the following sentence: Am vergangenen Freitag nahm der Grossvater des Herzogs, mit Rücksicht auf die Beschwerden der Untertanen, an einer Sitzung in der Hauptstadt teil. In this sentence only the articles and prepositions are German, the rest are assimilated loan-translations and loan-words, which are found in every dictionary, not specially marked as foreign, but treated like native German words. It is important to be aware of one's own language and to find a middle way between the original language and foreign influences.

\section{Bibliography}

Abdulaziz, M.H. 1989. Development of Scientific and Technical Terminology with Special Reference to African Languages. Kiswahili 56: 32-49.

Batibo, Herman M. 1992. Term Development in Tanzania. Stevenson, I.A. (Ed.). 1995: 27-38.

Batibo, Herman M. 1996. Loanword Clusters Nativization Rules in Tswana and Swahili: A Comparative Study. South African Journal of African Languages 16(2): 33-41.

Britz, R.M.J. 1983. Vreemdetaalbeinvloeding op die leksikon van isiXhosa. Unpublished D.Litt. thesis. Port Elizabeth: University of Port Elizabeth.

Cooper, Robert L. 1989. Language Planning and Social Change. Cambridge: University Press.

Fellmann, J. and J.A. Fishman. 1977. Language Planning in Israel: Solving Terminological Problems. Rubin, J. et al. (Eds.). 1977: 79-95.

Fishman, J.A. 1983. Modeling Rationales in Corpus Planning: Modernity and Tradition in Images of a Good Corpus. Cobarrubias, Juan and J.A. Fishman (Eds.). Progress in Language Planning: International Perspectives: 107-118. The Hague: Mouton.

Jafta, N. 1987. The Development of Terminology in Xhosa — A Case Study. Logos 7(2): 127-138.

Kirkness, A. 1976. Zur Lexikologie und Lexikographie des Fremdworts. Moser, H. 1976. Probleme der Lexikologie und Lexikographie. Düsseldorf: Schwann.

Rubin, J. and Jernudd, B.H. (Eds.). 1971. Can Language be Planned? Hawaii: University Press.

Rubin, J. et al. (Eds.). 1977. Language Planning Processes. The Hague: Mouton.

Stevenson, I.A. (Ed.). 1995. Sociolinguistics for Applied Linguistics. Reader for HSOPER-U. Pretoria: UNISA.

Tauli, Valter. 1968. Introduction to a Theory of Language Planning. Uppsala: Almqvist and Wiksells. Wahrig, Gerhard. 1968. Deutsches Wörterbuch. Gütersloh: Brockhaus. 